\title{
Structural basis of lignocellulose deconstruction by the wood-feeding anobiid beetle Nicobium hirtum
}

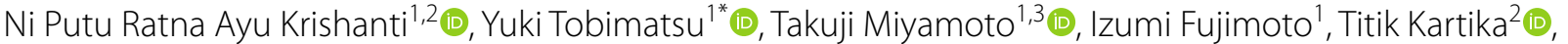 \\ Toshiaki Umezawa ${ }^{1}$ (D) Toshimitsu Hata ${ }^{1}$ (D) and Tsuyoshi Yoshimura ${ }^{1+\wedge}$
}

\begin{abstract}
The details of the lignocellulose deconstruction processes in the digestive systems of wood-feeding insects remain elusive. This study aimed to examine the biochemical conversion of lignocellulose in the digestive system of a woodfeeding anobiid beetle, Nicobium hirtum, one of the most important pests of wooden products in Japan. To this end, N. hirtum larvae were fed with Japanese red pine (softwood) and Japanese beech (hardwood) sapwood diets, as well as an artificial diet containing Shorea wood (hardwood) sapwood sawdust. The structural differences between the original and digested (feces) lignocellulose samples were examined using wet-chemical and two-dimensional (2D) nuclear magnetic resonance (NMR) methods. Cellulose and hemicelluloses, especially mannan in the softwood diet, were preferentially degraded over lignin in the larval digestive system. As a result, lignin was enriched in the digested lignocellulose residues. Lignin compositional analyses based on thioacidolysis and 2D NMR determined that the proportions of oxidized lignin aromatic units were notably increased after digestion. Further, the 2D NMR analyses revealed the accumulation of aldehyde and hydroxypropiovanillone/syringone end-unit structures in lignin, indicating that oxidative and/or reductive modifications of lignin polymers occur in the larval digestive system. Such structural alterations of lignin may facilitate the dissociation of the lignin barrier, thereby liberating polysaccharides for subsequent enzymatic conversion for assimilation and energy.
\end{abstract}

Keywords: Anobiid, Death-watch beetle, Lignocellulose, Nicobium hirtum, Nuclear magnetic resonance, Woodfeeding insect, Xylophagous insects

\section{Introduction}

Wood-feeding or xylophagous insects are mainly distributed in the three major orders of Insecta, i.e., Coleoptera (beetles), Blattodea (cockroaches and termites) and Hymenoptera (ants, bees, and wasps) [1]. They comprise important wood consumers (e.g., termites) that have a significant impact on wood decay and carbon recycling in terrestrial ecosystems [2]. Many are also recognized

*Correspondence: ytobimatsu@rish.kyoto-u.ac.jp

${ }^{\wedge}$ Tsuyoshi Yoshimura-Deceased May 18, 2021

${ }^{1}$ Research Institute for Sustainable Humanosphere (RISH), Kyoto

University, Gokasho, Uji 611-0011, Japan

Full list of author information is available at the end of the article as wood pests because they can inflict severe damage on economically important forest trees and dry wood materials [1]. These wood-feeding insects have developed unique and diverse digestive systems, often associated with intestinal microbial symbionts, which can produce the enzymes necessary to decompose lignocellulose, the recalcitrant biocomposite of cellulose, hemicelluloses, and lignin that constitutes woody plant cell walls [2-6]. There is much to learn about the mechanisms underlying lignocellulose digestion by wood-feeding insects, i.e., how they achieve efficient hydrolysis and subsequent conversion of polysaccharides (cellulose and hemicelluloses) for assimilation and energy, and also how they circumvent recalcitrant lignin barriers to gain access to 
the embedded polysaccharides. These topics are receiving considerable research attention, not only to better understand the physiology and evolution of herbivorous insects [7], but also to develop biotechnological strategies for wood pest management [6] and methods to produce biochemicals from lignocellulosic biomass [8].

In recent years, lignocellulose deconstruction processes in insect gut digestive systems have been revisited through structural analyses of digested lignocellulose residues in feces using advanced analytical techniques. In particular, recent studies employing pyrolysis-gas chromatography/mass spectrometry (Py-GC/MS) [9-13] and/or two-dimensional (2D) nuclear magnetic resonance (NMR) spectroscopy [13-15] have detected differential degradation patterns of cell wall polysaccharides, i.e., cellulose and hemicelluloses, as well as evidence of previously overlooked chemical alterations of lignin polymers during their passage through the insect digestive systems. Nevertheless, these structural studies are still limited to a small number of insect species, mostly termites (Blattodea). With regard to beetles (Coleoptera), although significant advances have been made in understanding the genetic and biochemical aspects of their lignocellulose degradation enzymes and gut microbial consortia $[2,12,16]$, structural basis of lignocellulose deconstruction in their digestive systems is yet to be defined. In this study, we close this gap by analyzing the digestive processes of the anobiid beetle, Nicobium hirtum (Coleoptera: Ptinidae).

$N$. hirtum is a representative species of "death-watch beetles" or "shiban-mushi" (in Japanese) found in Japan. It is one of the most important wood pests, especially for cultural wooden structures and artifacts, in the country [17-19]. It prefers seasoned wood and subsists on both softwood and hardwood, apparently indiscriminately [17, 18]. The attacked wood can be recognized by $2-3 \mathrm{~mm}$ round holes on the surface (Fig. 1a) and, more indicatively, by the cylindrical fecal pellets (frass) produced by the larvae (Fig. 1b). The adult beetles are 3 to $7 \mathrm{~mm}$ long and reddish-to-blackish brown with slender antennae
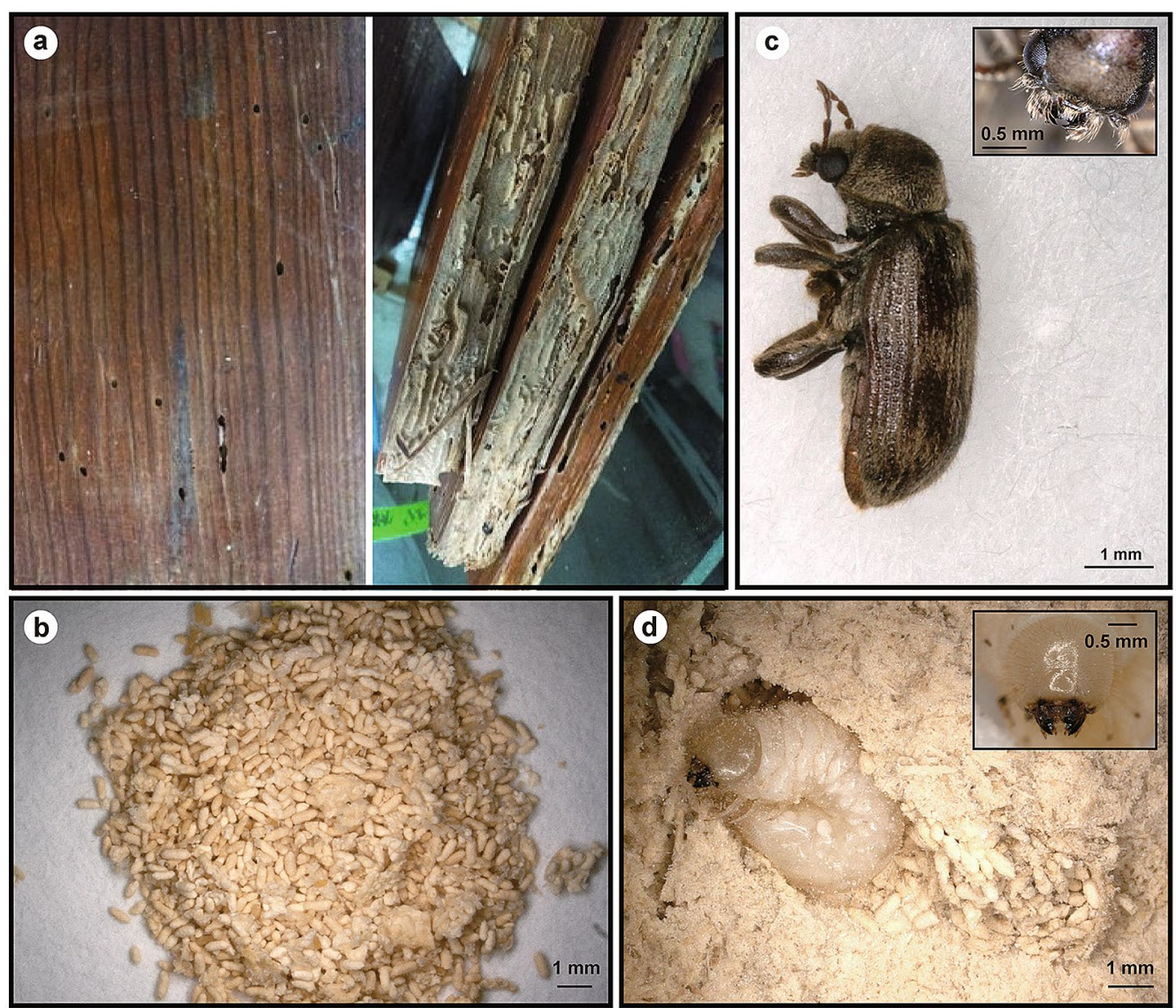

Fig. 1 Damage caused by Nicobium hirtum and appearance of adults and larvae. Appearance of wooden furniture attacked by N. hirtum (a), cylindrical larval fecal pellets (b), and morphology of $N$. hirtum adult beetle (c) and larva (d). Inserts are magnified facial views showing toothed mandibles of $N$. hirtum adult beetle $(\mathbf{c})$ and larva $(\mathbf{d})$ 
that consist of 11 flattened segments (Fig. 1c). The larvae are typically up to $7 \mathrm{~mm}$ long, with a creamy-white scarabaeiform (c-shaped) appearance (Fig. 1d). Although both the adult beetles and larvae have powerful toothed mandibles that enable them to bore wood (Fig. 1c, d), most damage is inflicted by larvae nesting inside woody tissues and using lignocellulose as the major carbon source. Although many Anobiidae members have been observed to utilize plant cell walls, little is yet known about the effects of different diets on the physiology of $N$. hirtum, and details of their lignocellulose degradation ability are largely unknown, despite their importance as notorious wood pests. In this study, we used a recently developed laboratory culture of $N$. hirtum [19] to conduct basic physiological characterizations of $N$. hirtum larvae fed on different lignocellulose diets. Further, we conducted in-depth structural characterizations of lignocellulose in their feces using a series of wet chemistry and 2D NMR methods.

\section{Materials and methods}

\section{Larvae feeding and feces collection}

The $N$. hirtum larvae were obtained from a laboratory colony recently developed at the Deterioration Organisms Laboratory (DOL), Research Institute for Sustainable Humanosphere, Kyoto University, Japan [19]. Sixty middle-stage instars of $N$. hirtum larvae were collected from the colony and placed on sapwood blocks $[2(L) \times 2$ $(W) \times 2(H) \mathrm{cm}]$ of Japanese red pine (Pinus densiflora) or Japanese beech (Fagus crenata), or artificial diet blocks $[2(L) \times 2(W) \times 2(H) \mathrm{cm}]$. The artificial diet consisted of $50 \%(\mathrm{w} / \mathrm{w})$ starch, $24 \%(\mathrm{w} / \mathrm{w})$ yeast extract, and $26 \%$ $(\mathrm{w} / \mathrm{w})$ Shorea sp. sawdust, and was originally designed to feed mass cultures of Lyctus species [20-22]. Each larva was placed in a hole in the center of the diet block and allowed to grow in an incubator maintained at $25^{\circ} \mathrm{C}$ and $65 \%$ relative humidity. The cylindrical fecal pellets (Fig. 1) were collected once a week for 5 months to obtain sufficient material for lignocellulose analysis. The collected feces were immediately frozen and kept at $-25{ }^{\circ} \mathrm{C}$ to prevent further degradation. After 5 months of feeding, the larvae survival rates were recorded, and the remaining diet blocks were oven-dried and weighed to determine the mass loss during the feeding period (Fig. 2). The obtained feces (digested) and original (undigested) diet samples were pulverized, washed successively with water and $80 \%$ ethanol, and then lyophilized to obtain cell wall residue (CWR) samples [15] for wet chemistry and 2D NMR analyses.

\section{Chemical analyses}

The starch content was determined by measuring the amount of glucose released by treatment with thermostable $\alpha$-amylase and amyloglucosidase according to Hattori et al. [23]. The contents of crystalline cellulose and noncrystalline glycan were determined by the two-step acid hydrolysis method using trifluoroacetic acid and sulfuric acid as described by Lam et al. [24]. The thioglycolic acid lignin assay for determination of lignin content [25] and analytical thioacidolysis for determination of lignin composition [26] were performed as described previously.

\section{D NMR analyses}

The CWR samples were finely ball-milled with a planetary micro mill (Pulverisette 7, Fritsch Industrialist, IdarOberstein, Germany) and swelled in $600 \mu \mathrm{L}$ dimethyl
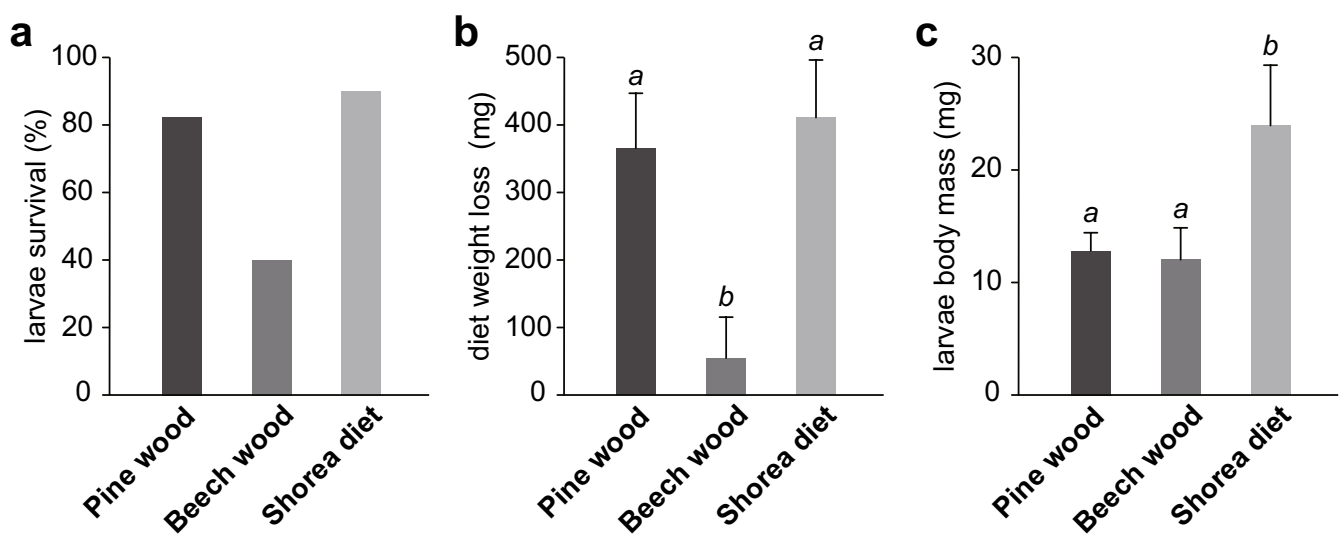

Fig. 2 Survival, feeding, and growth of N. hirtum larvae fed with different diets. Larvae survival (a), lignocellulose diet weight loss (b), and larvae body mass (c) of N. hirtum larvae after 5 months of feeding on Chinese red pine (softwood), Japanese beech (hardwood), or a Shorea (hardwood) artificial diet. Values in $\mathbf{b}$ and $\mathbf{c}$ are means \pm SD $(n=20)$. Different letters indicate significant differences (one-way ANOVA with Tukey HSD test, $p<0.05)$ 
sulfoxide (DMSO) $-d_{6} /$ pyridine- $d_{5}(4: 1, \mathrm{v} / \mathrm{v})$ before wholecell-wall NMR analysis [27-29]. Adiabatic 2D heteronuclear single quantum coherence (HSQC) NMR spectra were acquired using a Bruker Avance III 800US system (800 MHz, Bruker Biospin, Billerica, MA, USA) fitted with a cryogenically cooled $5 \mathrm{~mm}$ TCI gradient probe (Bruker Biospin) using the standard Bruker implementation method ('hsqcetgpsp.3') and acquisition parameters described previously [27-29]. Data processing and analysis were performed using Bruker TopSpin 4.1 (MacOS) software (Bruker Biospin) as described previously [13, 15, 30]. Peak assignments were conducted by comparison of chemical shift data with data reported in the literature [13, 27-29, 31]. For volume integration analysis of the lignin aromatic unit and polysaccharide anomeric signals (Fig. 3), $\mathrm{C} 2-\mathrm{H} 2$ correlations from guaiacyl units $\left(\mathbf{G}_{\mathbf{2}}\right.$ and $\left.\mathbf{G}_{2}{ }_{2}\right), \mathrm{C} 2-\mathrm{H} 2 / \mathrm{C} 6-\mathrm{H} 6$ correlations from syringyl units $\left(\mathbf{S}_{\mathbf{2 / 6}}\right.$ and $\left.\mathbf{S}_{\mathbf{2 / 6}}^{\prime}\right)$, and $\mathrm{C} 1-\mathrm{H} 1$ correlations from the major polysaccharide units $\left(\mathbf{G l}_{1}, \mathbf{M}_{1}, \mathbf{M}^{\prime}{ }_{1}, \mathbf{M}^{\prime \prime}{ }_{1}, \mathbf{X}_{1}, \mathbf{X}^{\prime}{ }_{1}\right.$, $\mathrm{X}_{1}^{\prime \prime}, \mathrm{X}^{\prime \prime \prime}{ }_{1}, \mathrm{~A}_{1}$, and $\mathrm{U}_{1}$ ) were manually integrated, and $S_{2 / 6}$ and $S_{2 / 6}^{\prime}$ integrals were logically halved. For analysis of lignin inter-monomeric and end-unit linkage types (Fig. 4), well-resolved $\mathrm{C} \alpha-\mathrm{H} \alpha$ contours from the lignin inter-monomeric linkages $\left(\mathbf{I}_{\boldsymbol{\alpha}}, \mathbf{I I}_{\boldsymbol{\alpha}}\right.$, and $\left.\mathbf{I I I}_{\boldsymbol{\alpha}}\right)$ and the benzaldehyde end-units $\left(\mathbf{I V}^{\prime \prime}{ }_{\alpha}\right), \mathrm{C} \gamma-\mathrm{H} \gamma$ contours from the cinnamaldehyde end-units $\left(\mathbf{I V}^{\prime}{ }_{\alpha}\right)$, and $\mathrm{C} \beta-\mathrm{H} \beta$ contours from the hydroxypropiovanilone (HPV)/hydroxypropiosyringone (HPS) end-units $\left(\mathbf{I V}^{\prime \prime \prime}{ }_{\beta}\right)$ were also manually integrated, and $\mathbf{I I I}_{\boldsymbol{\alpha}}$ and $\mathbf{I V}^{\prime \prime \prime}{ }_{\beta}$ integrals were logically halved $[13,15,30]$.

\section{Statistical analysis}

Student's $t$-test $(p<0.05)$ and one-way analysis of variance (ANOVA) followed by Tukey's honestly significant difference (HSD) test $(p<0.05)$ were performed using IBM SPSS statistics version 27 (IBM Corporation, Armonk, NY, USA).

\section{Results}

\section{Physiological characteristics of $N$. hirtum larvae fed on lignocellulose diets}

We recorded larvae survival, the decrease in the mass of the lignocellulose diet, and the growth (change in body mass) of the larvae fed on three different lignocellulose diets, i.e., plain sapwood blocks of Japanese red pine (softwood) and Japanese beech (hardwood), and an artificial diet block consisting of Shorea (hardwood) sapwood sawdust, yeast extract, and starch. Our preliminary experiments indicated that this Shorea woodbased artificial diet, which was originally developed for feeding powder-post beetles (Lyctus species) in the laboratory [20-22], is suitable for the maintenance of $N$. hirtum larvae [19]. The survival rates of the larvae fed with the pine wood and the Shorea artificial diet were similarly high $(>80 \%)$, whereas that of the larvae fed with the beech wood diet was considerably lower (ca. 40\%) (Fig. 2a). Consistent with this result, the larvae consumed significantly less of the beech wood diet than the other two diets (Fig. 2b). The body mass of the larvae fed with the Shorea artificial diet was significantly higher than those of the larvae fed with the pine and beech plain wood diets (Fig. 2c). This result emphasizes the importance of starch and protein (yeast extract) as nutrients for the survival and growth of $N$. hirtum larvae, even though they subsist on, and utilize, lignocellulose as the major carbon source in nature.

\section{Changes in lignocellulose composition after passage through the digestive system of $N$. hirtum larvae}

To understand the lignocellulose deconstruction processes in the digestive system of $N$. hirtum larvae, we subjected the CWR samples prepared from the original and digested (feces) lignocellulose diets to a series of lignocellulose compositional analyses using wet-chemical methods. We could not collect sufficient feces for analyses from the larvae fed on the beech wood diet, mainly because of the low larval survival rate (Fig. 2a). Therefore, we report the results obtained for the digested pine wood and Shorea artificial diet samples. The cell wall structural data of the original beech wood diet sample used in this study were reported in our earlier study [15].

The sugar and lignin content analyses indicated that the digested pine wood and Shorea artificial diet lignocelluloses were both depleted in polysaccharides and proportionally augmented in lignin (Table 1 ). This result shows that, as reported for many other wood-feeding insects, $N$. hirtum larvae digest primarily polysaccharides, leaving a majority of lignin polymers in fecal digestive residues. For the pine wood diet that contained little starch (ca. $0.3 \%$ of CWR), the contents of crystalline glucan as well as mannan were notably reduced after digestion (Table 1), demonstrating that $N$. hirtum larvae can digest cellulose and hemicelluloses, especially mannan. For the Shorea artificial diet, which contained abundant starch, $N$. hirtum larvae preferentially digested starch over cellulose and hemicelluloses (Table 1). Nevertheless, we detected notable decreases in the contents of amorphous glucan and mannan in the digested Shorea artificial diet, indicative of the digestion of hemicellulosic glycans. Interestingly, xylan was significantly augmented in the digested samples of pine wood and Shorea artificial diets, compared with the original diets (Table 1). This result suggests that $N$. hirtum larvae are less able to digest xylan than other cell wall polysaccharide components, such as cellulosic glucan and hemicellulosic mannan, in lignocellulose. 

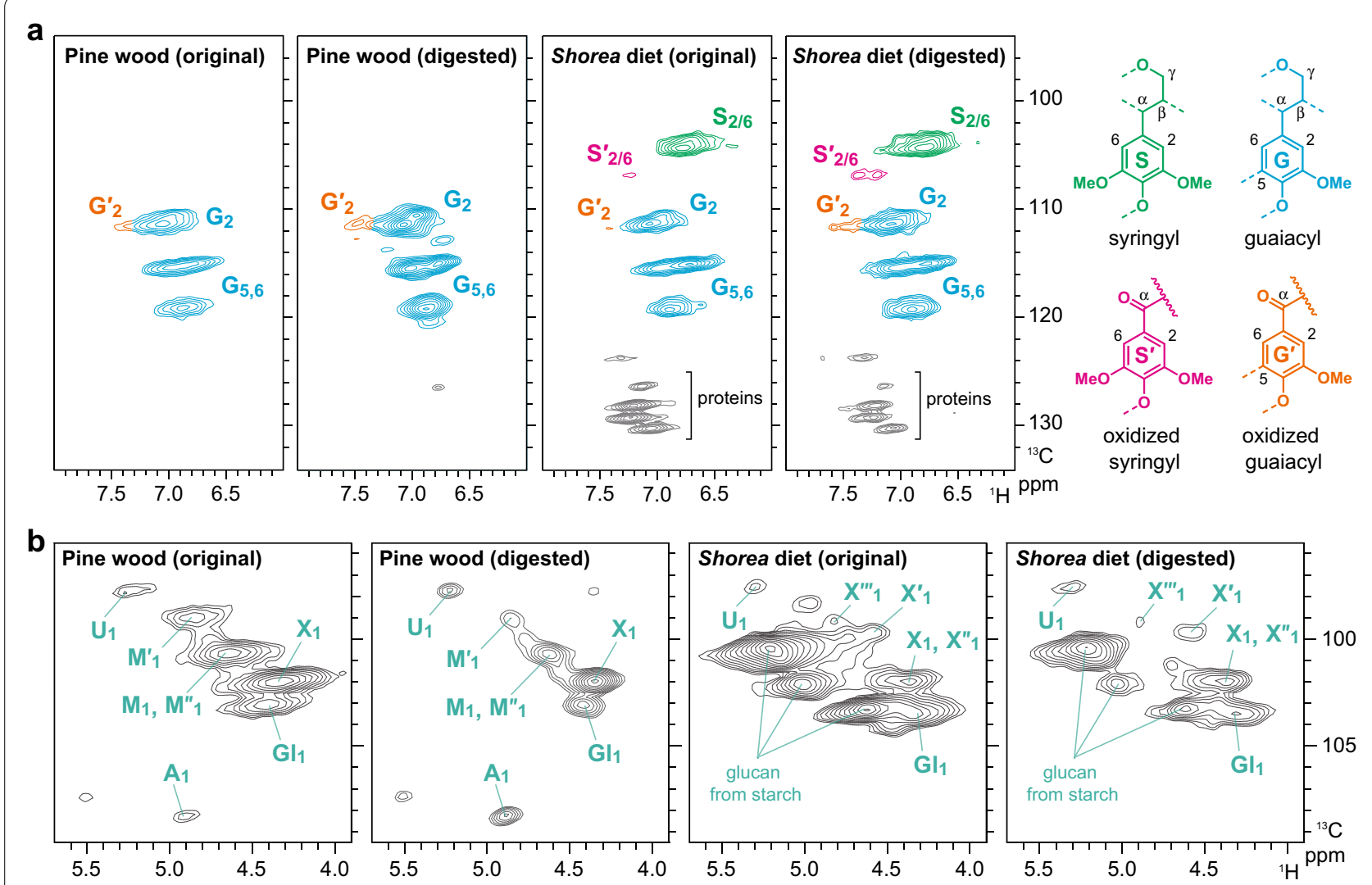
GI: glucan
M: mannan
$\mathrm{X}$ : xylan
A: arabinan
U: glucuronan
M': 2-O-Ac mannan
$X^{\prime}:$ 2-O-Ac xylan
X": 3-O-Ac xylan
X"': 2,3-di-O-Ac xylan

C

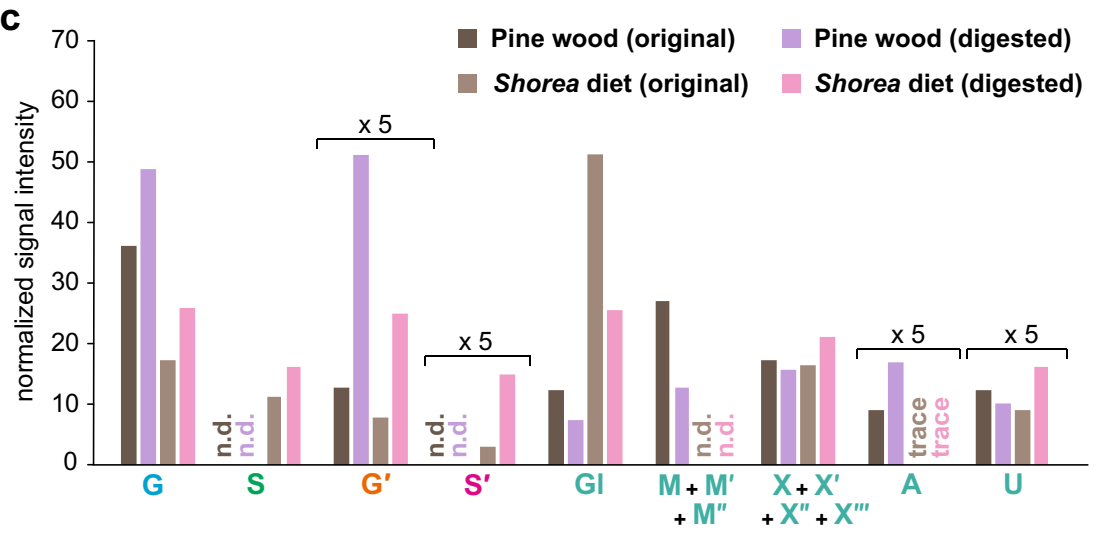

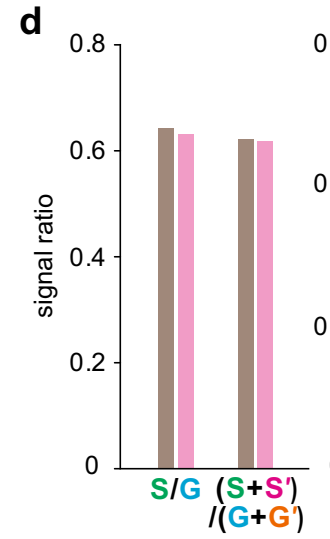

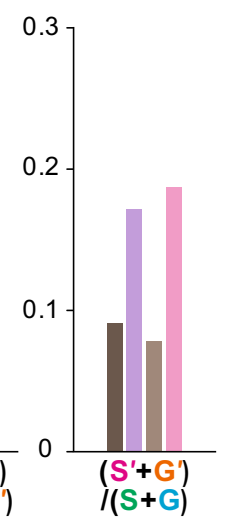

Fig. 3 Lignin aromatic units and polysaccharides in original and digested diet samples of N. hirtum. Aromatic (a) and polysaccharide anomeric (b) sub-regions 2D HSQC NMR spectra of pine wood and Shorea artificial diet lignocellulose samples before ("original") and after ("digested") digestion by N. hirtum larvae. Figures show normalized signal intensity values of major lignin aromatic and polysaccharide anomeric signals expressed as percentages of the sum of the listed signals (see Materials and methods) (c) and ratios of non-oxidized and oxidized syringyl $\left(1 / 2 \mathbf{S}_{2 / 6}\right.$ and $1 / 2 \mathbf{S}_{2 / 6}^{\prime}$ ) and guaiacyl $\left(\mathbf{G}_{\mathbf{2}}\right.$ and $\mathbf{G}_{\mathbf{2}}^{\prime}$ ) lignin aromatic signals (d). Data labeled $\times 5$ indicate that the reported values are multiplied by 5 for visualization purposes. Peak assignments are listed in Table 2 


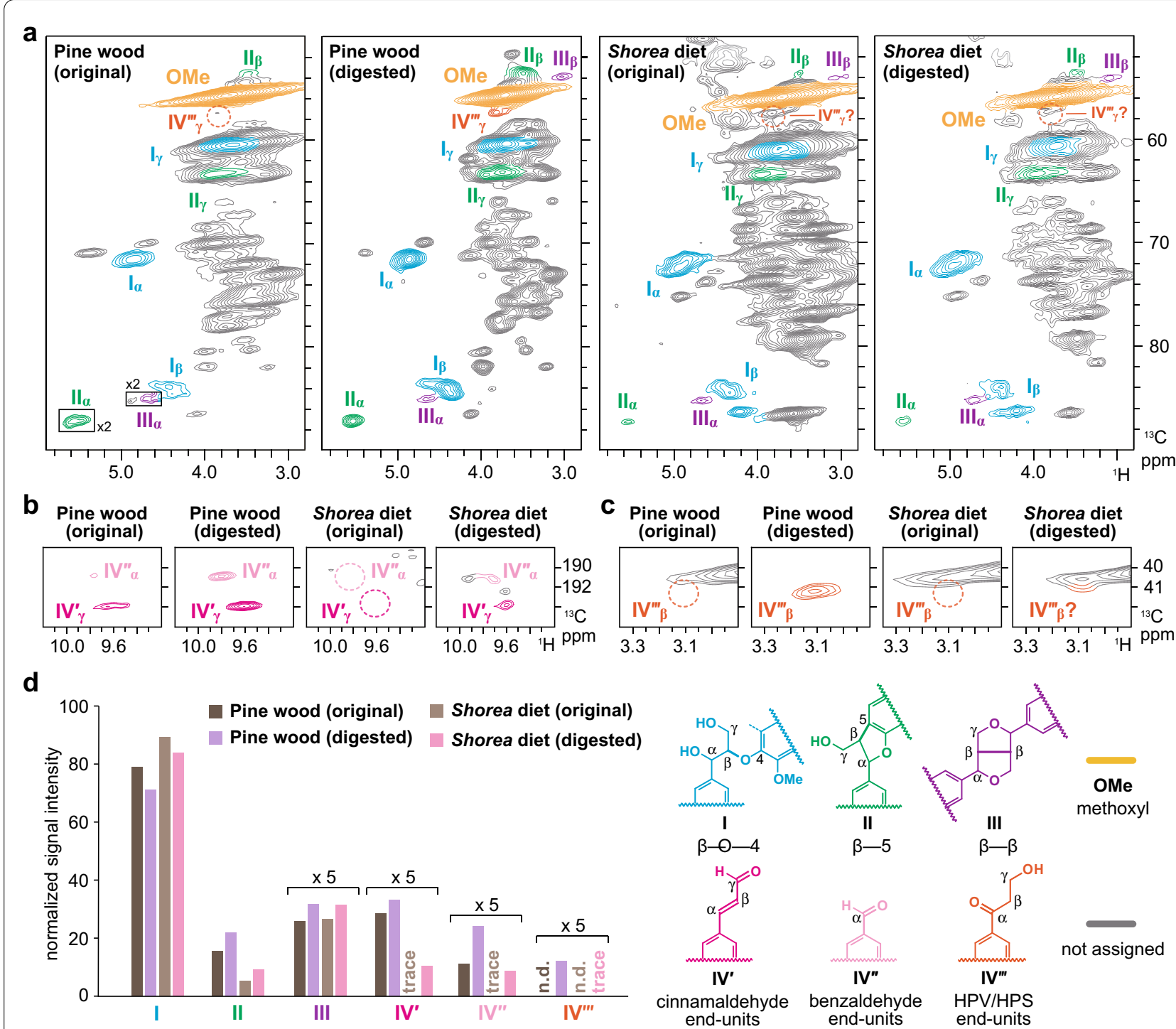

Fig. 4 Lignin inter-monomeric and end-unit linkage types in undigested and digested diets of N. hirtum. Oxygenated aliphatic (a and c) and aldehyde (b) sub-regions of 2D HSQC NMR spectra of pine wood and Shorea artificial diet lignocellulose samples before ("original") and after ("digested") digestion by $\mathrm{N}$. hirtum larvae. Boxes labeled $\times 2$ represent regions with the scale vertically enlarged by twofold. In $\mathbf{d}$, normalized signal intensity values of the major lignin inter-monomeric linkage types $\left(\mathbf{I}_{\mathbf{a}^{\prime}} \mathbf{I}_{\mathbf{a}}\right.$ and $\left.1 / 2 \mathbf{I} \mathbf{I} \mathbf{a}_{\mathbf{a}}\right)$ and aldehyde $\left(\mathbf{I} \mathbf{V}_{\boldsymbol{\gamma}^{\prime}}\right.$ and $\left.\mathbf{I} \mathbf{V}^{\prime \prime}{ }_{\mathrm{a}}\right)$ and HPV/HPS $\left(1 / 2 \mathbf{I} \mathbf{V}^{\prime \prime \prime}{ }_{\beta}\right)$ end-unit signals expressed as percentages of $\mathbf{I}_{\mathbf{a}}+\mathbf{I}_{\mathbf{a}}+\mathbf{1}_{\mathbf{1}} \mathbf{I} \mathbf{I}_{\mathrm{a}}$ are shown. Data labeled $\times 5$ indicate that the reported values are multiplied by 5 for visualization purposes. Peak assignments are listed in Table 2

\section{In-depth lignocellulose structural analyses by 2D NMR and thioacidolysis}

To obtain further detailed chemical information on the digestion of lignocellulose diets by $N$. hirtum larvae, we performed in-depth cell wall structural analysis by collecting 2D HSQC NMR spectra of the whole CWR samples via the direct dissolution/swelling method with the DMSO- $d_{6} /$ pyridine- $d_{5}$ solvent system $[27,28]$. The obtained HSQC spectra of the pine wood and Shorea artificial diet lignocellulose samples displayed major lignin and polysaccharide signals typical of softwood and hardwood, respectively (Fig. 3). Peak assignments based on chemical shift data reported in the literature [13, 2729, 31] are listed in Table 2.

The aromatic sub-regions $\left(\delta_{\mathrm{C}} / \delta_{\mathrm{H}}, 140-100 / 8.0-6.0\right)$ of the pine wood HSQC spectra displayed aromatic signals typical of softwood lignin composed of only guaiacyl (G) units ( $\mathbf{G}$ and $\left.\mathbf{G}^{\prime}\right)$, whereas the spectra of the Shorea diets additionally displayed signals from syringyl (S) units (S and $\mathbf{S}^{\prime}$ ) typical of hardwood lignin (Fig. 3a and Table 2). 
Table 1 Composition of samples before (original) and after (digested) digestion by N. hirtum larvae

\begin{tabular}{|c|c|c|c|c|c|c|}
\hline & \multicolumn{3}{|c|}{ Pine wood diet } & \multicolumn{3}{|c|}{ Shorea artificial diet } \\
\hline & Original $^{a}$ & Digested $^{a}$ & \%Change $^{\mathrm{b}}$ & Original $^{\mathrm{a}}$ & Digested $^{\mathrm{a}}$ & $\%$ Change ${ }^{b}$ \\
\hline \multicolumn{7}{|c|}{ Polysaccharide contents (wt\% per CWR) } \\
\hline Starch & $0.30 \pm 0.0$ & $0.02 \pm 0.4^{*}$ & -93 & $40.8 \pm 2.2$ & $26.4 \pm 3.1^{*}$ & -35 \\
\hline Crystalline glucan & $30.7 \pm 4.1$ & $24.2 \pm 0.8^{*}$ & -21 & $28.2 \pm 2.4$ & $33.4 \pm 2.1^{*}$ & +19 \\
\hline Amorphous glucan & $5.0 \pm 0.1$ & $4.7 \pm 0.3$ & -5 & $3.0 \pm 0.2$ & $2.2 \pm 0.1^{*}$ & -28 \\
\hline Mannan & $7.6 \pm 0.1$ & $6.0 \pm 0.4^{*}$ & -21 & $2.9 \pm 0.2$ & $1.1 \pm 0.1^{*}$ & -62 \\
\hline Xylan & $3.3 \pm 0.1$ & $4.2 \pm 0.1^{*}$ & +26 & $4.0 \pm 0.4$ & $4.7 \pm 0.1^{*}$ & +20 \\
\hline Arabinan & $1.2 \pm 0.0$ & $1.5 \pm 0.1$ & +30 & $0.2 \pm 0.0$ & $0.2 \pm 0.1$ & -5 \\
\hline Galactan & $1.3 \pm 0.1$ & $1.8 \pm 0.1$ & +38 & $0.4 \pm 0.1$ & $0.4 \pm 0.1$ & \pm 0 \\
\hline \multicolumn{7}{|c|}{ Lignin content (wt\% per CWR) } \\
\hline & $20.5 \pm 1.4$ & $35.7 \pm 1.5^{*}$ & +73 & $10.8 \pm 0.5$ & $21.2 \pm 0.3^{*}$ & +90 \\
\hline \multicolumn{7}{|c|}{ Lignin composition (mol\% per $\mathrm{S}+\mathrm{G}+\mathrm{H}$ ) } \\
\hline Syringyl, $\mathbf{S}$ & n.d & n.d & - & $50.3 \pm 0.7$ & $45.6 \pm 1.3^{*}$ & -9 \\
\hline Guaiacyl, G & $99.3 \pm 0.1$ & $99.5 \pm 0.1$ & \pm 0 & $49.6 \pm 0.7$ & $54.3 \pm 1.3^{*}$ & +10 \\
\hline p-Hydroxyphenyl, $\mathbf{H}$ & $0.7 \pm 0.1$ & $0.6 \pm 0.1$ & -22 & $0.1 \pm 0.1$ & $0.2 \pm 0.1$ & +36 \\
\hline $\mathbf{S} / \mathbf{G}$ ratio & - & - & - & $1.02 \pm 0.03$ & $0.84 \pm 0.05^{*}$ & -17 \\
\hline
\end{tabular}

n.d., not detected.

${ }^{\text {a }}$ Values are means \pm standard deviation from triplicated runs. Asterisks $\left(^{*}\right)$ indicate significant differences between original and digested lignocellulose diets (Student's $t$-test, $p<0.05$ ).

${ }^{b}$ Bold values indicate significant decrease or increase in digested compared with original lignocellulose diets

The polysaccharide anomeric sub-regions $\left(\delta_{\mathrm{C}} / \delta_{\mathrm{H}}, 110-\right.$ 90/4.0-5.5) displayed anomeric signals associated with cellulose and hemicellulose: glucans (Gl); unacetylated (M) and acetylated $\left(\mathbf{M}^{\prime}\right.$ and $\left.\mathbf{M}^{\prime \prime}\right)$ mannans (in the pine wood spectra); unacetylated $(\mathbf{X})$ and acetylated $\left(\mathbf{X}^{\prime}, \mathbf{X}^{\prime \prime}\right.$, and $\mathbf{X}^{\prime \prime \prime}$ ) xylans (in the Shorea diet spectra); arabinan (A); glucuronan (U). In addition, the Shorea artificial diet spectra displayed intense signals from aromatic amino acids [31] and starch glucans, which could be attributed to the protein (yeast extract) and starch components of this diet (Fig. 3b and Table 2).

For comparison between the original and digested lignocellulose diet spectra, the major lignin aromatic and cell wall polysaccharide anomeric signals were integrated and normalized based on the sum of the integrated signals (Fig. 3c). Consistent with the chemical analysis data (Table 1), the lignin aromatic signals were all proportionally augmented, whereas polysaccharide signals, especially those from glucan and mannan, were depleted in the spectra of digested lignocellulose compared with the spectra of lignocellulose in the original diets (Fig. 3c). This result provided further evidence that $N$. hirtum larvae preferentially digested polysaccharides, especially cellulosic glucan and hemicellulosic mannan, over lignin in these lignocellulose diets. For the Shorea artificial diet spectra, signals from proteins (Fig. 3a) and starch glucan (Fig. 3b) were clearly depleted after digestion, although they are not included in the integration analysis data presented in Fig. 3c. This result confirmed the more efficient digestion of starch and protein than Shorea lignocellulose in this artificial diet.

The changes in lignin composition as a result of its passage through the $N$. hirtum larval digestive system were examined by comparing the HSQC signal intensities of the non-oxidized and oxidized $\mathrm{G}$ and $\mathrm{S}$ aromatic signals $\left(\mathbf{G}, \mathbf{G}^{\prime}, \mathbf{S}\right.$ and $\mathbf{S}^{\prime}$ ) (Fig. 3d). In addition, we conducted a complementary lignin compositional analysis using thioacidolysis (Table 1), which quantifies lignin-derived monomeric compounds released from non-oxidized $\beta-\mathrm{O}-4$ units in the lignin polymer [32]. The results of the 2D HSQC NMR (Fig. 3d) and thioacidolysis (Table 1) analyses consistently showed that the ratio of non-oxidized $\mathrm{S}$ and $G$ lignin units (S/G ratio) was slightly reduced in the digested Shorea artificial diet compared with the original diet. It was noticeable that there were some deviations between the HSQC-derived $\mathbf{S} / \mathbf{G}$ signal ratio and the thioacidolysis-derived S/G monomer ratio. This could be at least partly attributed to the fact that thioacidolysis measures only the S/G unit ratio in the monomers released by cleaving $\beta-\mathrm{O}-4$ bonds, whereas HSQC NMR estimates the $S / G$ unit distribution in the entire lignin polymers. Further, the HSQC NMR results also revealed that the oxidized $G$ and $S$ signals $\left(\mathbf{G}^{\prime}\right.$ and $\left.\mathbf{S}^{\prime}\right)$ were proportionally augmented over non-oxidized $\mathrm{G}$ and $\mathrm{S}$ signals $(\mathbf{G}$ and $\mathbf{S})$ in the spectra of the digested pine wood and Shorea artificial diets (Fig. 3d). These results indicate 
Table 2 Assignment of polysaccharide and lignin signals in ${ }^{1} \mathrm{H}-{ }^{13} \mathrm{C}$ correlation (HSQC) spectra of pine and Shorea diet cell wall samples

\begin{tabular}{|c|c|c|}
\hline Labels & $\delta_{\mathrm{C}} / \delta_{\mathrm{H}}(\mathrm{ppm})$ & Assignment \\
\hline \multicolumn{3}{|c|}{ Cell wall polysaccharide signals } \\
\hline $\mathrm{Gl}_{1}$ & $103.3 / 4.40$ & $\mathrm{C} 1-\mathrm{H} 1$ in $(1 \rightarrow 4)-\beta$-D-glucopyranosyl units \\
\hline$M_{1}$ & 100.6/4.65 & $\mathrm{C} 1-\mathrm{H} 1$ in $(1 \rightarrow 4)-\beta-\mathrm{D}-\mathrm{mannopyranosyl}$ units \\
\hline $\mathbf{M}_{1}^{\prime}$ & 99.0/4.87 & $\mathrm{C} 1-\mathrm{H} 1$ in 2-O-acetyl- $\beta$-D-mannopyranosyl units \\
\hline$M^{\prime \prime}{ }_{1}$ & $100.6 / 4.65$ & $\mathrm{C} 1-\mathrm{H} 1$ in 3-O-acetyl- $\beta$-D-mannopyranosyl units \\
\hline$x_{1}$ & 102.0/4.34 & $\mathrm{C} 1-\mathrm{H} 1$ in $(1 \rightarrow 4)-\beta$-D-xylopyranosyl units \\
\hline $\mathbf{X}^{\prime}{ }_{1}$ & $99.7 / 4.59$ & $\mathrm{C} 1-\mathrm{H} 1$ in 2-O-acetyl- $\beta$-D-xylopyranosyl units \\
\hline $\mathrm{X}^{\prime \prime}{ }_{1}$ & 102.0/4.34 & $\mathrm{C} 1-\mathrm{H} 1$ in 3-O-acetyl- $\beta$-D-xylopyranosyl units \\
\hline $\mathrm{X}^{\prime \prime}{ }_{1}$ & $75.1 / 4.95$ & $\mathrm{C} 1-\mathrm{H} 1$ in 2-O-acetyl- $\beta$-D-xylopyranosyl units \\
\hline $\mathrm{X}^{\prime \prime \prime}{ }_{1}$ & $98.3 / 4.96$ & $\mathrm{C} 1-\mathrm{H} 1$ in 2,3-di-O-acetyl- $\beta$-D-xylopyranosyl units \\
\hline$A_{1}$ & 108.2/4.90 & $\mathrm{C} 1-\mathrm{H} 1$ in a-L-arabinofuranosyl units \\
\hline $\mathrm{U}_{1}$ & $97.7 / 5.27$ & $\mathrm{C} 1-\mathrm{H} 1$ in a-D-glucuronopyranosyl units \\
\hline \multicolumn{3}{|c|}{ Lignin signals } \\
\hline $\mathrm{G}_{2}$ & $111.2 / 7.07$ & $\mathrm{C} 2-\mathrm{H} 2$ in guaiacyl units \\
\hline $\mathrm{G}_{5,6}$ & $115.3 / 6.95,119.1 / 6.87$ & $\mathrm{C} 5-\mathrm{H} 5$ and $\mathrm{C} 6-\mathrm{H} 6$ in guaiacyl units \\
\hline$S_{2 / 6}$ & $104.3 / 6.77$ & $\mathrm{C} 2-\mathrm{H} 2$ and $\mathrm{C} 6-\mathrm{H} 6$ in syringyl units \\
\hline $\mathrm{G}_{2}^{\prime}$ & $111.7 / 7.42$ & $\mathrm{C} 2-\mathrm{H} 2$ in oxidized guaiacyl units \\
\hline $\mathbf{S}_{2 / 6}^{\prime}$ & $106.8 / 7.23$ & $\mathrm{C} 2-\mathrm{H} 2$ and $\mathrm{C} 6-\mathrm{H} 6$ in oxidized syringyl units \\
\hline $\mathrm{I}_{\mathrm{a}}$ & $71.6 / 4.87$ & $\mathrm{Ca}-\mathrm{Ha}$ in $\beta-\mathrm{O}-4$ substructures \\
\hline$I_{\beta}$ & $84.2 / 4.36,86.3 / 4.18$ & $C \beta-H \beta$ in $\beta-O-4$ units \\
\hline$I_{\gamma}$ & $60.6 / 3.72$ & $\mathrm{C}_{Y}-\mathrm{H}_{\gamma}$ in $\beta-\mathrm{O}-4$ units \\
\hline $\mathrm{II}_{\mathrm{a}}$ & $87.3 / 5.53$ & $\mathrm{Ca}-\mathrm{Ha}$ in $\beta-5$ units \\
\hline$\|_{\beta}$ & $53.6 / 3.48$ & $\mathrm{C} \beta-\mathrm{H} \beta$ in $\beta-5$ units \\
\hline$I I_{\gamma}$ & $63.1 / 3.74$ & $\mathrm{C}_{Y}-\mathrm{H}_{\gamma}$ in $\beta-5$ units \\
\hline $\mathrm{III}_{\mathrm{a}}$ & $85.1 / 4.65$ & $\mathrm{Ca}-\mathrm{Ha}$ in $\beta-\beta$ units \\
\hline $\mathrm{III}_{\beta}$ & $53.9 / 3.02$ & $C \beta-H \beta$ in $\beta-\beta$ units \\
\hline $\mathbf{I V}_{\gamma}^{\prime}$ & 193.9/9.61 & $\mathrm{C}_{\gamma}-\mathrm{H} \gamma$ in cinnamaldehyde end-units \\
\hline $\mathbf{I V}^{\prime \prime}{ }_{a}$ & 190.9/9.80 & $\mathrm{Ca}-\mathrm{Ha}$ in benzaldehyde end-units \\
\hline $\mathrm{IV}^{\prime \prime \prime}{ }_{\beta}$ & $41.2 / 3.11$ & $\mathrm{C} \beta-\mathrm{H} \beta$ in $\mathrm{HPV} / \mathrm{HPS}$ end-units \\
\hline $\mathbf{I V}^{\prime \prime \prime}{ }_{\gamma}$ & $57.2 / 3.81$ & $\mathrm{CY}_{\mathrm{H}} \mathrm{H} Y$ in $\mathrm{HPV} / \mathrm{HPS}$ end-units \\
\hline OMe & $3.72 / 55.8$ & Methyl $\mathrm{C}-\mathrm{H}$ in aromatic methoxyl groups \\
\hline \multicolumn{3}{|l|}{ Others } \\
\hline- & $100.4 / 5.20,102.1 / 5.01,103.3 / 4.62$ & $\mathrm{C} 1-\mathrm{H} 1$ in starch glucans \\
\hline - & $126.2 / 7.12,128.1 / 7.20,129.1 / 7.27,130.1 / 7.05$ & Aromatic $\mathrm{C}-\mathrm{H}$ in aromatic protein residues \\
\hline
\end{tabular}

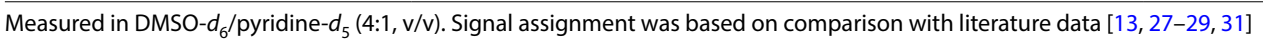

that lignin can be structurally modified during its passage through the $N$. hirtum larvae digestive system, as further demonstrated below.

To further examine the lignin structures in the digested lignocellulose diets, we analyzed lignin inter-monomeric and end-unit linkage signals appearing in the oxygenated-aliphatic and aldehyde sub-regions of the HSQC NMR spectra (Fig. 4 and Table 2). Typical lignin linkage signals from $\beta-\mathrm{O}-4(\mathbf{I}), \beta-5$ (II), and $\beta-\beta$ (III) units were clearly visible in both the original and digested lignocellulose diet spectra (Fig. 4a). Volume integration analysis of the relatively well-resolved $\mathrm{C} \alpha-\mathrm{H} \alpha$ signals revealed differences in the distributions of these major inter-monomeric linkage types between the original and digested lignin samples (Fig. 4d). For both the pine wood and Shorea artificial diets, the inter-monomeric linkage distribution patterns were similar between the original and digested lignocellulose, suggesting that the structural modifications occurring in the $N$. hirtum larvae digestive system were not drastic. However, for both of the lignocellulose diets, the $\beta-\mathrm{O}-4$ unit signals (I) were proportionally decreased, whereas the $\beta-5$ (II) and $\beta-\beta$ (III) 
signals were proportionally increased, after digestion (Fig. 4d). We also detected increases in the cinnamaldehyde (IV') and benzaldehyde (IV') end-units in the spectra of the digested lignocellulose samples (Fig. 4b and d). Moreover, a set of signals attributed to the HPV/HPS end-units (IV'"'), most diagnostically $\mathrm{C} \beta-\mathrm{H} \beta\left(\mathbf{I V}^{\prime \prime \prime}{ }_{\beta}\right)$ at $\delta_{\mathrm{C}} / \delta_{\mathrm{H}}=41.2 / 3.11$ and $\mathrm{C} \gamma-\mathrm{H} \gamma\left(\mathbf{I V}^{\prime \prime \prime}{ }_{\gamma}\right)$ at $\delta_{\mathrm{C}} / \delta_{\mathrm{H}}=57.2 / 3.81$ $[13,33]$, was clearly detected in the digested pine wood spectrum, although the appearance of $\mathbf{I V}^{\prime \prime \prime}$ in the Shorea artificial diet spectrum was unclear, probably because of the relatively low lignin content. In contrast, these HPV/ HPS (IV'") signals were undetectable in the spectra of the original lignocellulose diets (Fig. 4a, c and d). The increments in these aldehydes and HPV/HPS lignin end-units were consistent with the increased signals of oxidized G and $S$ lignin units in the digested lignocellulose (Fig. 3), providing further evidence that lignin polymers undergo partial structural modifications during their passage through the $N$. hirtum larvae digestive system.

\section{Discussion}

As reported for several other wood-feeding beetles [1, 8], the larvae of the anobiid beetle $N$. hirtum can subsist on plain softwood (pine) and hardwood (beech) lignocellulose diets and utilize them as a sole carbon source, although adding starch and protein into the hardwood (Shorea) lignocellulose diet can greatly promote their survival and growth (Fig. 2). The larvae physiology data suggested that $N$. hirtum larvae prefer softwood to hardwood as a lignocellulose-based carbon source. Although $N$. hirtum larvae attacks both softwood and hardwood, apparently indiscriminately $[17,18]$, some Anobiidae members reportedly attack softwoods preferentially over hardwoods [34-36]. Our chemical and 2D NMR analyses of the original and digested lignocellulose diets clearly demonstrated that $N$. hirtum larvae are able to decompose cell wall polysaccharides, i.e., cellulose and hemicelluloses. Upon feeding with the plain pine wood diet containing little residual starch, the larvae digested both cellulose and hemicelluloses along with residual starch. On the other hand, cellulose digestion was apparently limited when they were fed with the Shorea artificial diet containing additional starch and protein (Table 1 and Fig. 3), suggesting that, in the presence of rich starch and protein sources, the larvae preferentially digest them over cell wall polysaccharides. Intriguingly, among the hemicellulosic glycans present in the pine and Shorea diets, mannan and amorphous glucan were preferentially digested over other glycans by $N$. hirtum larvae (Table 1 and Fig. 3). The fact that $N$. hirtum larvae preferentially digest mannan and glucan, which represent the major hemicellulosic sugars in softwood (as glucomannan) [37], may be associated with the positive nutritional effects of the softwood diet over the hardwood diet on larval survival and growth (Fig. 2).

The ability of $N$. hirtum larvae to degrade cellulose and hemicellulose indicate potential roles of plant cell walldegrading enzymes (PCWDEs) in the gut digestive system. Such enzymes may originate from either the beetle host or its gut-resident microbial symbionts, or both. Recent genomic studies have emphasized the importance of the endogenous PCWDEs in beetles [2, 3, 7, 16], many of which are thought to have originated from bacteria or fungi via horizontal gene transfer during the evolution and biodiversification of herbivorous beetles [16, 38]. Indeed, endogenous PCWDE genes, including those encoding glycoside hydrolase $(\mathrm{GH})$ family proteins that typically show cellulolytic and hemicellulolytic activities, have been detected in the genomes and transcriptomes of beetles (Coleoptera) including powder-post beetles in the Bostrichoidea superfamily, to which $N$. hirtum and other anobiid species belong $[2,16]$. With respect to the notable activity of $N$. hirtum larvae to degrade mannan, several endogenous genes in beetles [2, 16, 39-42] and genes in their gut-resident bacteria $[12,31,43,44]$ encoding PCWDEs with putative mannan-degrading activities (e.g., $\beta$-mannosidase and endo- $\beta$-1,4-mannanase) have been reported. It is conceivable that these PCWDEs secreted from the beetle host and/or its gut-resident microbial symbionts enable $N$. hirtum larvae to efficiently digest cellulose and hemicelluloses, especially mannans, for assimilation and energy.

To efficiently degrade cell wall polysaccharides, $N$. hirtum larvae must overcome the lignin barrier to allow PCWDEs to contact the embedded polysaccharide substrates. The digested lignocellulose diets showed markedly increased $(>70 \%)$ lignin contents, alongside proportional decreases in polysaccharide contents (Table 1 and Fig. 3). This result indicates that, as reported in other lignocellulose digestion experiments with other lignocellulose-feeding insects $[10,11,15,45,46]$, polysaccharide decomposition exceeds lignin decomposition and a large proportion of lignin polymers remains intact in the digestive residues. Nevertheless, our in-depth lignin structural analyses, primarily by 2D HSQC NMR, detected several notable signatures indicative of partial structural modifications of lignin, including potential cleavages of the lignin polymer backbone, after its passage through the $N$. hirtum larvae digestive system.

For both the softwood (pine) and hardwood (Shorea) diets, the oxidized $G$ and $S$ lignin units $\left(\mathbf{G}^{\prime}\right.$ and $\left.\mathbf{S}^{\prime}\right)$ were proportionally increased over the non-oxidized $G$ and $S$ lignin units (G and $\mathbf{S}$ ) after digestion (Fig. 3). We also detected proportional decreases of the major $\beta-\mathrm{O}-4$ linkage type (I) over the other major lignin inter-monomeric linkage types (II and III). More indicatively, we 
detected augmentations of the aldehyde (IV' and $\mathbf{I V}^{\prime \prime}$ ) and HPV/HPS (IV") end-unit structures (Fig. 4), both of which are implicated in oxidative and/or reductive lignin biodegradation pathways as further discussed below. These lignin structural modifications, which are presumably facilitated by gut symbionts, could contribute to the deconstruction of the lignin barrier and the subsequent liberation and digestion of cellulose and hemicelluloses in the gut digestive system. A recent lignocellulose structural study conducted using 2D NMR and Py-GC/MS techniques also detected increased contents of aldehyde and HPV/HPS lignin end-unit structures in wheat straw biomass digested by termite gut microbiomes [13]. Analogous lignin degradation mechanisms may be involved in the beetle digestive system studied here.

The HPV/HPS structures in lignin have been documented in lignin degraded by $\beta$-etherases, which catalyze the reductive cleavage of the $\beta-\mathrm{O}-4$ linkages under anaerobic conditions [47, 48]. Functional lignin $\beta$-etherases have been characterized from several ligninolytic bacterial strains [49-52], and homologous $\beta$-etherase genes are widely distributed in bacteria [53, $54]$, including those present as symbionts in the beetle gut [12]. To date, however, the activities of these $\beta$-etherases have been tested mostly in reactions with dimeric lignin substrates [49-51], whereas an earlier study detected HPV/HPS compounds released from polymeric lignin substrates treated with the $\beta$-etherase pathway enzymes in vitro [52]. On the other hand, it has been also documented that these HPV/HPS structures in lignin can arise from oxidative lignin degradation pathways of white rot fungi under aerobic conditions $[33,55,56]$. As further discussed below, previous research suggests that beetle digestive tracts have steep oxygen gradients allowing for the coexistence of aerobic and anaerobic microorganisms in different gut compartments [57]. Thus, it is conceivable that HPV/HPS lignin structures can be generated by both reductive and oxidative lignin degradation pathways in insect digestive systems.

The aldehyde end-unit structures in lignin are typical consequences of oxidative lignin degradation and are commonly observed in lignin materials biodegraded by wood-decaying fungi $[33,58]$. Previous lignocellulose structural studies primarily using Py-GC/MS detected signatures of lignin side-chain oxidation by the woodfeeding beetles, Anoplophora glabripennis (Cerambycidae) [9] and Odontotaenius disjunctus (Passalidae) [12]. Lignin side-chain oxidation has also been observed after digestion of lignin by several termite species as revealed by Py-GC/MS and/or 2D NMR [9-11, 13]. Although the oxidative lignin degradation pathways of fungi harboring strong lignin oxidases (e.g., lignin peroxidases and laccases) have been well documented [59], it is currently unclear whether such intensive oxidation reactions occur in insect gut digestive systems. Notably, however, a recent metagenomic study on the digestive tract of the woodfeeding beetle Odontotaenius disjunctus detected several bacterial genes encoding enzymes associated with oxidative lignin degradation, such as laccases, peroxidases, and dioxygenases. They were found to be particularly enriched in the midgut and posterior hindgut regions, which provide relatively aerobic environments with oxygen supplied from the trachea, making them suitable for oxidative degradation of lignocellulose [12]. Similar gut anatomical properties and assemblies of microbial communities may also play important roles in lignin degradation in the $N$. hirtum larvae digestive system.

\section{Conclusions}

Our results show that the larvae of the Anobiid beetle $N$. hirtum are able to deconstruct lignocellulose in their gut digestive system. The larvae can subsist on plain softwood and hardwood lignocelluloses, utilizing cellulose and hemicelluloses, especially mannans, for assimilation and energy. Such efficient polysaccharide digestion could be achieved by overcoming lignin barriers through structural modifications of lignin polymers via reductive and/or oxidative degradation pathways. Further studies should profile gut microbial communities and conduct functional analyses of the endogenous and symbiotic genes/enzymes potentially involved in lignocellulose deconstruction. The results of such studies will shed light on the unique digestive physiology that has developed and evolved among wood-feeding insects. Such information may be used to develop technologies to prevent the destruction of woody materials by these notorious pests and develop new strategies for the sustainable utilization of lignocellulosic biomass.

\section{Abbreviations \\ ANOVA: Analysis of variance; CWR: Cell wall residue; DMSO: Dimethyl sulfoxide: G: Guaiacyl; GH: Glycoside hydrolase; HPS: Hydroxypropiosyringone; HPV: \\ Hydroxypropiovanilone; HSD: Honestly significant difference; HSQC: Heteronu- clear single quantum coherence; NMR: Nuclear magnetic resonance; PCWDE: Plant cell wall-degrading enzyme; Py-GC/MS: Pyrolysis-gas chromatography/ mass spectrometry; S: Syringyl; 2D: Two-dimensional.}

\section{Acknowledgements}

The authors thank Dr. Hironori Kaji and Ms. Ayaka Maeno (ICR, Kyoto University) for their support in NMR experiments, Mr. Akio Adachi (RISH, Kyoto University) for technical assistance, and Dr. Didi Tarmadi and Dr. Khoirul Himmi S. (Research Center for Biomaterials, BRIN) for helpful discussions. Part of this study was conducted using the facilities in the DOL and DASH/ FBAS at RISH, Kyoto University and the NMR spectrometer at the JURC of ICR, Kyoto University.

\section{Authors' contributions}

NPRAK, YT, TU, and TY conceived the research. NPRAK, YT, TM, IF and TY designed experiments. NPRAK, YT, TM, and TY performed experiments and 
analyzed data with TK, TH, and TU. NPRAK and YT wrote the manuscript with help from all other authors. All authors read and approved the final manuscript.

\section{Funding}

This study was supported in part by the Japan Society for the Promotion of Science KAKENHI Grants (JP2OH03044). NPRAK acknowledges a Ph.D. scholarship from MEXT of Japan.

\section{Availability of data and materials}

The datasets used and/or analyzed during the current study are available from the corresponding author on reasonable request.

\section{Declarations}

\section{Competing interests}

The authors declare that they have no competing interests.

\section{Author details}

${ }_{1}^{1}$ Research Institute for Sustainable Humanosphere (RISH), Kyoto University, Gokasho, Uji 611-0011, Japan. ${ }^{2}$ Research Center for Biomaterials, National Research and Innovation Agency of Indonesia (BRIN), Jl. Raya Bogor km. 46 Cibinong, Bogor 16911, Indonesia. ${ }^{3}$ Present Address: Sakeology Center, Niigata University, 8050 Ikarashi 2-no-cho, Nishi-ku, Niigata 950-2181, Japan.

Received: 14 November 2021 Accepted: 7 February 2022 Published online: 21 February 2022

\section{References}

1. Pournou A (2020) Wood deterioration by insects In: biodeterioration of wooden cultural heritage. Springer, Cham

2. Tokuda G (2019) Plant cell wall degradation in insects: recent progress on endogenous enzymes revealed by multi-omics technologist. Adv Insect Physiol 57:97-136. https://doi.org/10.1016/bs.aiip.2019.08.001

3. Watanabe H, Tokuda G (2010) Cellulolytic systems in insects. Annu Rev Entomol 55:609-632. https://doi.org/10.1146/annur ev-ento-112408-085319

4. Ni J, Tokuda G (2013) Lignocellulose degrading enzymes from termites and their symbiotic microbiota. Biotechnol Adv 31:838-850. https://doi. org/10.1016/j.biotechadv.2013.04.005

5. Brune A (2014) Symbiotic digestion of lignocellulose in termite guts. Nat Rev Microbiol 12:168-180. https://doi.org/10.1038/nrmicro3182

6. Douglas AE (2015) Multiorganismal insects: diversity and function of resident microorganisms. Annu Rev Entomol 60:17-34. https://doi.org/ 10.1146/annurev-ento-010814-020822

7. Calderon-Cortes N, Quesada M, Watanabe H, Cano-Camacho H, Oyama K (2012) Endogenous plant cell wall digestion: a key mechanism in insect evolution. Annu Rev Ecol Evol Syst 43:45-71. https://doi.org/10.1146/ annurev-ecolsys-110411-160312

8. Sun J, Zhou XJ (2011) Utilization of lignocellulose-feeding insects for viable biofuels: an emerging and promising area of entomological science. In: Liu T, Kang L (eds) Recent advances in entomological research. Springer, Berlin

9. Geib SM, Filley TR, Hatcher PG, Hoover K, Carlson JE, Jimenez-Gasco MdM, Nakagawa-Izumi A, Sleighter RL, Tien M (2008) Lignin degradation in wood-feeding insects. Proc Natl Acad Sci USA 105:12932-12937. https:// doi.org/10.1073/pnas.0805257105

10. Ke J, Laskar DD, Singh D, Chen S (2011) In situ lignocellulosic unlocking mechanism for carbohydrate hydrolysis in termites: crucial lignin modification. Biotechnol Biofuel 4:1-12. https://doi.org/10.1186/1754-6834-4-17

11. Ke J, Laskar DD, Chen S (2013) Varied lignin disruption mechanisms for different biomass substrates in lower termite. Renew Energy 50:10601064. https://doi.org/10.1016/j.renene.2012.08.069

12. Ceja-Navarro JA, Karaoz U, Bill M, Hao Z, White RA III, Arellano A, Ramanculova L, Filley TR, Berry TD, Conrad ME, Blackwell M, Nicora CD, Kim YM, Reardon PN, Lipton MS, Adkins JN, Pett-Ridge J, Brodie EL (2019) Gut anatomical properties and microbial functional assembly promote lignocellulose deconstruction and colony subsistence of a wood-feeding beetle. Nat Microbiol 4:864-875. https://doi.org/10.1038/ s41564-019-0384-y

13. Dumond L, Lam PY, van Erven G, Kabel M, Mounet F, Grima-Pettenati J, Tobimatsu Y, Hernandez-Raquet G (2021) Termite gut microbiota contribution to wheat straw delignification in anaerobic bioreactors. ACS Sustainable Chem Eng 9:2191-2202. https://doi.org/10.1021/acssuschem eng.0c07817

14. Li H, Yelle DJ, Li C, Yang M, Ke J, Zhang R, Liu Y, Zhu N, Liang S, Mo X, Ralph J, Currie CR, Mo J (2017) Lignocellulose pretreatment in a fungus-cultivating termite. Proc Natl Acad Sci USA 114:4709-4714. https://doi.org/10. 1073/pnas.1618360114

15. Tarmadi D, Tobimatsu Y, Yamamura M, Miyamoto T, Miyagawa Y, Umezawa T, Yoshimura T (2018) NMR studies on lignocellulose deconstructions in the digestive system of the lower termite Coptotermes formosanus Shiraki. Sci Rep 8:1290. https://doi.org/10.1038/s41598-018-19562-0

16. McKenna DD, Shin S, Ahrens D, Balke M, Beza-Beza C, Clarke DJ, Beutel RG (2019) The evolution and genomic basis of beetle diversity. Proc Natl Acad Sci USA 116:24729-24737. https://doi.org/10.1073/pnas.19096 55116

17. Yamano K (2003) Insect damage to wooden cultural properties and countermeasures (in Japanese). Wood Ind (Mokuzai Kogyo) 58:576-581

18. Komine $Y$ (2019) The deathwatch beetles as a pest to cultural properties. TOBUNKENNEWS 69:45-47

19. Fujimoto I, Yoshimura T (2018) Establishment of mass cultures of woodattacking beetles. Sustain Human 14:13

20. Kartika T, Yoshimura T (2015) Evaluation of wood and cellulosic materials as fillers in artificial diets for Lyctus africanus Lesne (Coleoptera: Bostrichidae). Insects 6:696-703. https://doi.org/10.3390/insects6030696

21. Kartika T, Nobuhiro S, Yoshimura T (2015) Identification of esters as novel aggregation pheromone components produced by the male powderpost beetle, Lyctus africanus Lesne (Coleoptera: Lyctinae). PLoS ONE 10:e0141799. https://doi.org/10.1371/journal.pone.0141799

22. Kartika T, Shimizu N, Himmi SK, Guswenrivo I, Tarmadi D, Yusuf S, Yoshimura T (2021) Influence of age and mating status on pheromone production in a powder-post beetle Lyctus africanus (Coleoptera: Lyctinae). Insects 12:8. https://doi.org/10.3390/insects12010008

23. Hattori T, Murakami S, Mukai M, Yamada T, Hirochika H, Ike M, Tokuyasu K, Suzuki S, Sakamoto M, Umezawa T (2012) Rapid analysis of transgenic rice straw using near-infrared spectroscopy. Plant Biotechnol 29:359-366. https://doi.org/10.5511/plantbiotechnology.12.0501a

24. Lam PY, Tobimatsu Y, Takeda Y, Suzuki S, Yamamura M, Umezawa T, Lo C (2017) Disrupting flavone synthase II alters lignin and improves biomass digestibility. Plant Physiol 174:972-985. https://doi.org/10.1104/pp.16. 01973

25. Suzuki S, Suzuki Y, Yamamoto N, Hattori T, Sakamoto M, Umezawa T (2009) High-throughput determination of thioglycolic acid lignin from rice. Plant Biotechnol 26:337-340. https://doi.org/10.5511/plantbiotechnology.26. 337

26. Yamamura M, Hattori T, Suzuki S, Shibata D, Umezawa T (2012) Microscale thioacidolysis method for the rapid analysis of substructures in lignin. Plant Biotechnol 29:419-423. https://doi.org/10.5511/plantbiotechnol ogy.12.0627a

27. Kim H, Ralph J (2010) Solution-state 2D NMR of ball-milled plant cell wall gels in DMSO- $d_{6} /$ Pyridine- $d_{5}$. Org Biomol Chem 8:576-591. https://doi. org/10.1039/b916070a

28. Mansfield SD, Kim H, Lu F, Ralph J (2012) Whole plant cell wall characterization using solution-state 2D NMR. Nat Protoc 7:1579-1589. https://doi. org/10.1038/nprot.2012.064

29. Tobimatsu Y, Takano T, Umezawa T, Ralph J (2019) Solution-state multidimensional NMR of lignins: approaches and applications In: Lignin biosynthesis functions, and economic significance. Nova Science Publishers Inc, Hauppauge

30. Miyamoto T, Mihashi A, Yamamura M, Tobimatsu Y, Suzuki S, Takada R, Kobayashi Y, Umezawa T (2018) Comparative analysis of lignin chemical structures of sugarcane bagasse pretreated by alkaline, hydrothermal, and dilute sulfuric acid methods. Ind Crops Prod 121:124-131. https://doi. org/10.1016/j.indcrop.2018.04.077

31. Kim H, Padmakshan D, Li Y, Rencoret J, Hatfield RC, Ralph J (2017) Characterization and elimination of undesirable protein residues in plant 
cell wall materials for enhancing lignin analysis by solution-state nuclear magnetic resonance spectroscopy. Biomacromolecules 18:4184-4195. https://doi.org/10.1021/acs.biomac.7b01223

32. Lapierre C, Monties B, Rolando C, de Chirale L (1985) Thioacidolysis of lignin: comparison with acidolysis. J Wood Chem Technol 5:277-292. https://doi.org/10.1080/02773818508085193

33. Van Erven G, Hilgers R, de Waard P, Gladbeek EJ, van Berkel WJH, Kabel MA (2019) Elucidation of in situ ligninolysis mechanisms of the selective white-rot fungus Ceriporiopsis subvermispora. ACS Sustain Chem Eng 7:16757-16764. https://doi.org/10.1021/acssuschemeng.9b04235

34. Koch P (1972) Utilization of southern pines-volume 1. Agricultural Handbook SFES-AH-420. USDA-forest service southern forest experiment station, Asheville

35. Robinson WH (2005) Handbook of urban insects and arachnids. Cambridge University Press, Cambridge

36. Heavilin J, Powell J, Logan JA (2007) Dynamics of mountain pine beetle outbreaks In: plant disturbance ecology. Academic Press, Cambridge

37. Albersheim P, Darvill A, Roberts K, Sederoff R, Staehelin A (2010) Plant cell walls garland science. Taylor and Francis Group, New York

38. Wybouw N, Pauchet Y, Heckel DG, Leeuwen TV (2016) Horizontal gene transfer contributes to the evolution of arthropod herbivory. Genome Biol Evol 8:1785-1801. https://doi.org/10.1093/gbe/evw119

39. Acuna R, Padilla BE, Florez-Ramos CP, Rubio JD, Herrera JC, Benavides P, Lee SJ, Yeats TH, Egan AN, Doyle JJ, Rose JKC (2012) Adaptive horizontal transfer of a bacterial gene to an invasive insect pest of coffee. Proc Nat Acad Sci USA 109:4197-4202. https://doi.org/10.1073/pnas.1121190109

40. Pauchet Y, Kirsch R, Giraud S, Vogel H, Heckel DG (2014) Identification and characterization of plant cell wall degrading enzymes from three glycoside hydrolase families in the cerambycid beetle Apriona japonica. Insect Biochem Mol Biol 49:1-13. https://doi.org/10.1016/j.ibmb.2014.03. 004

41. Vega FE, Brown SM, Chen H, Shen E, Nair MB, Ceja-Navarro JA, Brodie EL, Infante F, Dowd PF, Pain A (2015) Draft genome of the most devastating insect pest of coffee worldwide: the coffee berry borer Hypothenemus hampei. Sci Rep 5:12525. https://doi.org/10.1038/srep12525

42. Busch A, Kunert G, Heckel DG, Pauchet Y (2017) Evolution and functional characterization of CAZymes belonging to subfamily 10 of glycoside hydrolase family 5 (GH5_10) in two species of phytophagous beetles. PLOS ONE 12:e0184305. https://doi.org/10.1371/journal.pone.0184305

43. Book AJ, Lewin GR, McDonald BR, Takasuka TE, Doering DT, Adams AS, Blodgett JAV, Clardy J, Raffa KF, Fox BG, Currie CR (2014) Cellulolytic Streptomyces strains associated with herbivorous insects share a phylogenetically linked capacity to degrade lignocellulose. Appl Environ Microbiol 80:4692-4701. https://doi.org/10.1128/AEM.01133-14

44. Ohashi K, Hataya S, Nakata A, Matsumoto K, Kato N, Sato W, CarlosShanley C, Beebe ET, Currie CR, Fox BG, Takasuka TE (2021) Mannose and mannobiose specific responses of insect associated cellulolytic streptomyces. Appl Environ Microbiol 87:e0271920. https://doi.org/10.1128/ AEM.02719-20

45. Hyodo F, Inoue T, Azuma JI, Tayasu I, Abe T (2000) Role of the mutualistic fungus in lignin degradation in the fungus-growing termite Macrotermes gilvus (Isoptera: Macrotermitinae). Soil Biol Biochem 32:653-658. https:// doi.org/10.1016/50038-0717(99)00192-3

46. Katsumata KS, Jin Z, Hori K, liyama K (2007) Structural changes in lignin of tropical woods during digestion by termite. Cryptotermes brevis J Wood Sci 53:419. https://doi.org/10.1007/s10086-007-0882-z

47. Masai E, Katayama Y, Fukuda M (2007) Genetic and biochemical investigations on bacterial catabolic pathways for lignin-derived aromatic compounds. Biosci Biotechnol Biochem 71:1-15. https://doi.org/10.1271/ bbb.60437

48. Bugg TDH, Ahmad M, Hardiman EM et al (2011) Pathways for degradation of lignin in bacteria and fungi. Nat Prod Rep 28:1883-1896. https://doi. org/10.1039/c1np00042j

49. Masai E, Katayama Y, Kawai S, Nishikawa S, Yamasaki M, Morohoshi N (1991) Cloning and sequencing of the gene a Pseudomonas paucimobilis enzyme that cleaves $\beta$-aryl ether. J Bacteriol 173:7950-7955. https://doi. org/10.1128/jb.173.24.7950-7955.1991

50. Gall DL, Ralph J, Donohue TJ, Noguera DR (2014) A group of sequencerelated sphingomonad enzymes catalyzes cleavage of $\beta$ aryl ether linkages in lignin $\beta$-guaiacyl and $\beta$-syringyl ether dimers. Environ Sci Technol 48:12454-12463. https://doi.org/10.1021/es503886d
51. Ohta Y, Nishi S, Hasegawa R, Hatada Y (2015) Combination of six enzymes of a marine Novosphingobium converts the stereoisomers of $\beta-\mathrm{O}-4$ lignin model dimers into the respective monomers. Sci Rep 5:15105. https:// doi.org/10.1038/srep15105

52. Gall DL, Kontur WS, Lan W, Kim H, Li Y, Ralph J, Donohue TJ, Noguera DR (2018) In vitro enzymatic depolymerization of lignin with release of syringyl, guaiacyl, and tricin units. Appl Environ Microbiol 84:e02076-e2117. https://doi.org/10.1128/AEM.02076-17

53. Kontur WS, Olmsted CN, Yusko LM, Niles AV, Walters KA, Beebe ET, Meulen KAV, Karlen SD, Gall DL, Noguera DR, Donohue TJ (2019) A heterodimeric glutathione s-transferase that stereo specifically breaks lignin's $\beta(r)$-aryl ether bond reveals the diversity of bacterial $\beta$-etherases. J Biol Chem 294:1877-1890. https://doi.org/10.1074/jbc.RA118.006548

54. Voß H, Heck CA, Schallmey M, Schallmey A (2020) Database mining for novel bacterial $\beta$-etherases, glutathione-dependent lignin-degrading enzymes. Appl Environ Microbiol 86:e02026-e2119. https://doi.org/10. 1128/AEM.02026-19

55. Kawai S, Umezawa T, Higuchi T (1987) $p$-Benzoquinone monoketals, novel degradation products of $\beta-\mathrm{O}-4$ lignin model compounds by Coriolus versicolor and lignin peroxidase of Phanerochaete chrysosporium. FEBS Lett 210:61-65. https://doi.org/10.1016/0014-5793(87)81298-X

56. Kawai S, Shoji Sl, Nabeta K, Okuyama H, Higuchi T (1990) Degradation of non-phenolic $\beta-\mathrm{O}-4$ lignin substructure model compounds by lignin peroxidase of Coriolus versicolor. J Japan Wood Res Soc (Mokuzai Gakkaishi) 36:126-132

57. Ceja-Navarro JA, Nguyem NH, Karaoz U, Gross SR, Herman DJ, Andersen GL, Bruns TD, Pett-Ridge J, Blackwell M, Brodie EL (2014) Compartmentalized microbial composition, oxygen gradients and nitrogen fixation in the gut of Odontotaenius disjunctus. ISME J 8:6-18. https://doi.org/10. 1038/ismej.2013.134

58. Yelle DJ, Wei D, Ralph J, Hammel KE (2011) Multidimensional NMR analysis reveals truncated lignin structures in wood decayed by the brown rot basidiomycete Postia placenta. Environ Microbiol 13:1091-1100. https:// doi.org/10.1111/j.1462-2920.2010.02417.x

59. Martínez AT, Camarero S, Ruiz-Dueñas FJ, Martínez MJ (2018) Biological lignin degradation. In: Beckham GT (ed) Lignin valorization: emerging approaches. Royal Society of Chemistry, Cambridge

\section{Publisher's Note}

Springer Nature remains neutral with regard to jurisdictional claims in published maps and institutional affiliations.

\section{Submit your manuscript to a SpringerOpen ${ }^{\circ}$ journal and benefit from:}

- Convenient online submission

- Rigorous peer review

- Open access: articles freely available online

- High visibility within the field

- Retaining the copyright to your article

Submit your next manuscript at $\boldsymbol{\nabla}$ springeropen.com 